\section{Relationship between information access, service quality, costs saving, cultural similarity and supporting service towards medical (dental) tourism patients' satisfaction}

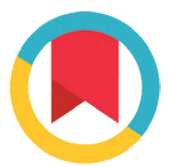

CrossMark

\author{
Fuad H. Akbar, ${ }^{1,2^{*}}$ Fridawaty Rivai, ${ }^{2}$ Andi Z. Abdullah, ${ }^{2}$ Abdul H. Awang ${ }^{3}$
}

\title{
Abstract
}

Objective: To determine the relationship between information access, service quality, cost savings, cultural similarities and supporting service systems towards dental tourism patient's satisfaction at Hospital X.

Material and Method: This study was an observational analytic study with a cross sectional approach. The analysis used in this study was performed using SPSS version 23 and correlation analysis.
Results: Service quality had a risk of 3.36 times affecting the level of satisfaction and access to information had a risk of 3.64 times affecting the level of satisfaction, and showed a statistically significant relationship $(p<0.05)$.

Conclusion: Research shows a statistically significant relationship between service quality and access to information on the level of patient satisfaction.

Keywords: Culture, Dental tourism, Satisfaction, Saving cost, Service quality

Cite this Article: Akbar FH, Rivai F, Abdullah AZ, Awang AH. 2021. Relationship between information access, service quality, costs saving, cultural similarity and supporting service towards medical (dental) tourism patients'satisfaction. Journal of Dentomaxillofacial Science 6(1): 31-34. DOl: $10.15562 / j d m f s . v 6 i 1.1106$

\begin{abstract}
1,2Department of Dental Public Health, Faculty of Dentistry, Hasanuddin University, Makassar, Indonesia

${ }^{2}$ Department of Hospital Management, Faculty of Public Health, Hasanuddin University, Makassar, Indonesia

${ }^{2}$ Department of Epidemiology, Faculty of Public Health, Hasanuddin University, Makassar, Indonesia ${ }^{3}$ Faculty of Social Sciences and Humanities, National University of Malaysia, Selangor, Malaysia
\end{abstract}

${ }^{*}$ Correspondence to: Fuad H. Akbar, Department of Dental Public Health, Faculty of Dentistry, Hasanuddin University, Makassar, Indonesia fuadgi2@gmail.com

Received: 4 April 2020 Revised: 26 May 2020 Accepted: 1 July 2020 Available Online: 1 April 2021

\section{Introduction}

Medical tourism is a term used to explain a phenomenon where people purposely travel outside of their home country to obtain medical services. Traditionally, privileged people from developing countries travel to obtain medical services in developed countries. However, current trends went the other way around, in which people from developed countries now travels to developing countries to get high quality medical service at a lower cost. Dental tourism is a type of medical tourism characterized by tourists accessing expensive costly dental treatment outside of their country of residence. ${ }^{1-8}$

Indonesian Republic Ministry of Health's Regulation Number 76 of 2015 concerning Medical Tourism Services considers that there is an everincreasing trend of medical tourists who travel both domestically and internationally to seek medical tourism. The number of patients crossing national borders in order to get medical care in lower-cost clinics continues to increase, this cross-border care is known as 'dental tourism'. Surge of patient's mobility is the result of various socioeconomic factors. First, dental treatments' costs are not affordable for numerous patients. Second, patient couldn't get a quick access to local dental care. Third, economic flights made transportation cost much cheaper. Fourth, the internet plays a vital role in the rise of individuals who travel for dental treatment. ${ }^{9,10-20}$
In Asia, four prime competing medical tourism destinations are Thailand, Singapore, Malaysia, and India. The state of Malaysia is one of the most prominent medical tourism destinations in Asia as well as the world. Besides being supported by attention-grabbing tourism destinations both in nature and culture, the country's ability to combine tourism and medicine is a key factor in the success of medical tourism in this country. The interesting fact about the high number of medical tourists who visits Malaysia is the origin of medical tourists, which is actually dominated by Indonesian citizen. In 2011, around 57\% of foreign tourists out of 583,296 medical tourists, namely 332,478 medical tourists came from Indonesia. This is certainly a very interesting subject to investigate, why so many Indonesians go to Malaysia for treatment. Also, to investigate the reasons behind Indonesian people's preference toward choosing Malaysia as a destination for their medical tourism activities. This means that perhaps most Indonesians doubts the quality of health services provided in Indonesia, so in the end they prefer to seek treatment in Malaysia. This phenomenon can of course cause detrimental effects for Indonesia and is a form of leakage in the economic sector. ${ }^{21,22}$

Based on the backgrounds explained above, several problems can be formulated, namely how 
is the relationship between access to information, service quality, cost savings, cultural similarity, supporting service systems for dental tourism patients' satisfactions at Hospital X?

\section{Material and Methods}

This study was an observational analytic study with cross sectional approach. This approach was employed to see the relationship between one variable and another. The sampling method used was accidental sampling. This study was conducted in hospital X. This study has obtained ethics from the Health Research Ethics Committee of the Hasanuddin University Dental Hospital with Ethical Approval number No.0028/PL.09/KLPK FKG- RSGM UNHAS/2020.

Inclusion criteria employed in this study were patients who got dental treatment in X hospital, willing to participate as a study subject, can read and write properly and was aged between 17 till 59 years old. Patients who didn't complete the questionnaire were excluded from this study.

Variable's assessment was conducted using questionnaire from research conducted by Jaapar
Information access, service quality, cost saving, cultural similarities, supporting service system were all assessed with a 5-point scale starting from 1 (very insignificant) to 5 (Very important), where study subjects will choose one out of the 5 numbers in which he/she perceives as the main reason. Satisfaction assessment used a 5-point scale starting from 1 (very dissatisfied) to 5 (very satisfied).

\section{Results}

Research has been conducted on the relationship between the quality of health services, cultural similarities and dental tourism patients' satisfaction. The study was conducted from February to April 2020. Total numbers of subjects included in this study were 100 participants.

All variable were assessed using questionnaire available in two languages namely English and Indonesian. Questionnaire were provided in printed and online in the form of 'google form'.

The results showed that service quality has a 3.36 times risks to affect the level of satisfaction and access to information has a 3.64 times risks to affect the level of satisfaction, and shows a significant

Table 1 Subjects distribution based on sociodemographic profile $(\mathbf{n}=100)$

\begin{tabular}{lll}
\hline Sociodemographic profile & $\mathbf{n}$ & $\%$ \\
\hline Gender & 88 & 88.0 \\
Male & 12 & 12.0 \\
Female & & \\
Age group & 43 & 43.0 \\
17-25 years & 37 & 37.0 \\
$26-35$ years & 18 & 18.0 \\
$36-45$ years & 2 & 2.0 \\
46-55 years & & \\
How do you pay for your treatment? & 46 & 46.0 \\
Cash & 42 & 42.0 \\
Insurance & 12 & 12.0 \\
Others & & \\
\hline
\end{tabular}

Source: Research data, 2020

Table 2 Results of the logistic regression test: service quality, information access, cultural similarity and level of satisfaction

\begin{tabular}{lcccc}
\hline \multirow{2}{*}{ Variable } & p value & & \multicolumn{2}{c}{ 95\% Cl OR } \\
\cline { 4 - 5 } & Odds Ratio & Lower & Upper \\
\hline Service quality $\rightarrow$ Level of satisfaction & 0.021 & 3.365 & 1.205 & 9.4 \\
Information access $\rightarrow$ Level of satisfaction & 0.009 & 3.645 & 1.378 & 9.64 \\
Cultural similarity $\rightarrow$ Level of satisfaction & 0.898 & 1.077 & 0.347 & 3.345 \\
Supporting service $\rightarrow$ Level of satisfaction & 0.244 & 2.296 & 0.567 & 9.295 \\
Cost saving $\rightarrow$ Level of satisfaction & 0.267 & 0.440 & 0.104 & 1.873 \\
\hline
\end{tabular}


relationship $(\mathrm{p}<0.05)$. The results also showed that cultural similarity does not have a significant relationship with the level of satisfaction and share the same results on supporting services \& cost savings on the level of satisfaction.

\section{Discussion}

Privileged people from developing countries tend to visit developed countries to seek medical treatments. But this trend is now reversed as more people from developed countries visits developing countries to seek better quality medical services at a lower cost. ${ }^{5}$

Numerous studies have revealed that dental treatment is considered as a very important medical treatment and account for $42 \%$ of medical services globally. ${ }^{23}$

Dental tourism is a type of medical tourism characterized by tourists accessing high-cost dental treatment outside of their country of residents. ${ }^{6}$

Some challenges faced by dental tourism patients are language and cultural barrier, environment, occupation, welfare, and insurance services that are unable to support medical and dental problems effecting body and dental will being in dental tourism patients. ${ }^{24}$

Oral health can affect individual physically and psychologically by inhibiting growth process, appearance, speech, mastication, taste, and loss of confidence. ${ }^{24}$

This study was conducted to assess the relationship between information access, service quality, cost savings, cultural similarities and supporting service systems in dental tourism towards dental health service satisfaction. The results showed that there was a significant relationship between service quality, access to information and level of satisfaction, the results also showed that cultural similarity had no significant relationship to the level of satisfaction. This is in line with the results of a research conducted in Malaysia in 2017, which used tourists as research subjects. The results of this study indicated that service quality and access to information have a significant relationship with patient satisfaction levels. ${ }^{5}$

Data shows that the existence of family members / relatives / friends in the destination country is a factor that contributes to the ease of access to information and recommendations obtained by dental tourism patients, hence in this study access to information has a risk of 3.64 times on the level of patient satisfaction. This is in line with research conducted in Italy in 2010, which showed that the aspect of access to information was significantly related to the satisfaction level of dental tourism patients when receiving dental services. The factors are the ease of obtaining information about the types of dental services and recommendations from family or relatives to determine which dental services will be received. ${ }^{25}$ Despite the increasing use of the internet, in several studies and in several medical tourism studies it has been found that word of mouth remains an important factor and the most important source of information. ${ }^{26,27}$

Data show stat high quality and standard of treatment, technology, certified clinics, qualified dentists, the availability of specialist services as well as care provided according to needs contributed highly to the quality of service in this study. This is in line with research conducted in Iran on matters that determine the high quality of dental care. ${ }^{28}$ Dental care standards relate to the professionalism of qualified and competent operators as required and licensed also accredited, dental clinic regulations, quality of dental education, assistant training, equipment selection and caring for patients based on special needs or personal care. ${ }^{6}$

Meanwhile, the relationship between cultural similarity and the level of satisfaction has no significant relationship. This is related to the availability of translators, so it affects the level of satisfaction of dental tourism patients. This research is in line with research conducted in Italy in 2010, which states that aspects of cultural similarity do not have a significant relationship with the satisfaction level of dental tourism patients when receiving dental services due to the large number of patients who complain about poor communication during treatment. ${ }^{29}$

Data shows that the convenient location of the clinic, transportation services, cosines of the waiting room for treatment, good service during visits to the clinic contributed highly to the quality of supporting services in this study. This is in line with research conducted in Vietnam, which shows that patients are satisfied with the doctors, nurses, clinical services, and clinical facilities that have been obtained in relation to the supporting services

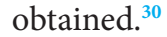

Regarding the results about cost savings on patients' satisfaction, it shows that dental care with affordable prices, quality accommodation, a good explanation of fees before starting treatment and the absence of additional fees also contributes highly to service quality in the cost saving category and the medium category related to ease of payment. Several studies have identified that affordable costs and easy access to dental care are the main reasons for the growing popularity of dental tourism. ${ }^{31}$

The concept of satisfaction includes two approaches; patient's satisfaction is seen as an attitude that results in confirmed or disconfirmed expectations (outcome perspective) or attitudes 
resulting from the level of patient expectations required for the service experience (process perspective). The quality of health services can be classified into three categories, namely structure, process, outcome. Structure, the attributes of the setting in which health services are implemented; process, shows what is actually done in giving and receiving health services; outcome, shows the effect of service on the patient's health status and population. ${ }^{32}$

\section{Conclusion}

Service quality and information access both have significant relationship with dental treatment satisfaction level in Hospital X. Whereas for cultural similarities, this aspect shows no significant relationship with dental services level of satisfaction. There are numerous things that affect patient's level of satisfaction; hence it is necessary to consider all aspects and things that can affect this which influence each other.

\section{Acknowledgment}

Thank you for the support from Hasanuddin University's Faculty of Dentistry and especially for the Department of Dental Public Health.

\section{Conflict of Interest}

The authors report no conflict of interest.

\section{References}

1. Johnston R, Crooks VA, Snyder J, et al. What is known about the effects of medical tourism in destination and departure countries? A scoping review. Int J Equity Health 2010;9: 24

2. Connell J. Reducing the scale? from global images to border crossings in medical tourism. Global Networks 2016;16: 531- 550 .

3. Crush J, Chikanda A. South-south medical tourism and the quest for health in southern Africa. Soc Sci Med 2014;124: 313- 320.

4. Jaapar M, Ghazali M, Sedigheh M, et al. Dental tourism: examining tourist profiles, motivation and satisfaction. Tourism Management 2017;61: 538- 552.

5. Turner L. "Dental tourism": issues surrounding crossborder travel for dental care. J Can Dent Assoc 2009;75: 117- 119.

6. Imison M, Schweinsberg S. Australian news media framing of medical tourism in low- and middle-income countries: a content review. BMC Public Health 2013;13: 109.

7. Qadeer I, Reddy S. Medical tourism in India: perceptions of physicians in tertiary care hospitals. Philos Ethics Humanit Med 2013;8: 20.

8. Nexhipi O, Moisiu A. Medical tourism management challengers: the case of dental tourism in Albania. Europ J Inerdiscip Stud 2018;4: 1- 7.

9. Turner L. Cross-border dental care: 'dental tourism' and patient mobility. Br Dent J 2008;2014: 553- 554.

10. Akbar FH, Anwar AI. The correlation between denture usage satisfactions on quality life of the elderly. J Dentomaxillofac Sci 2017;2: 100-104.
11. Moghavvemi S, Ormond M, Musa G, et al. Connecting with perspective medical tourists online: A cross sectional analysis of private hospital websites promoting medical tourism in India, Malaysia and Thailand. Tour Manag 2017;58: 154- 163.

12. Barrowman R, Grubor D, Chandu A. Dental implant tourism. Aust Dent J 2010;55: 441- 445.

13. Musa G, Thirumoorthi T, Doshi D. Travel behaviour among inbound medical tourists in Kuala Lumpur. Curr Issues Tourism 2011;15: 525- 543.

14. Yeoh E, Othman K, Ahmad, H. Understanding medical tourists: Word-ofmouth and viral marketing as potent marketing tools. Tour Manag 2013;34: 196- 201.

15. Kamath K, Hugar S, Kumar V, et al. The business and pleasure of teeth: dental tourism. Int J Contemp Dent Med Rev 2015;4: 1- 5 .

16. Osterle A, Baláz P, Delgado J. Travelling for teeth: characteristics and perspectives of dental care tourism in Hungary. Bri Dent J 2009;206: 425- 428.

17. Piazolo M, Zanca NA. Medical tourism - a case study for the USA and India, Germany and Hungary. Acta Polytech Hung 2011;8: 137- 160.

18. Zhang J, Seo S, Lee H. The impact of psychological distance on Chinese customers when selecting an international healthcare service country. Tour Manag 2013;35: 32- 40.

19. Zailani S, Mohezar AS, Iranmanesh M, et al. Predicting muslim medical tourists' satisfaction with Malaysian Islamic friendly hospitals. Tour Manag 2016;57: 159- 167.

20. Carmagnola, D, Filippucci L, Celestino S, et al. A survey on the experience with dental tourism in a sample of Italian patients. Minerva Stomatol 2011;61: 11- 20.

21. Kovacs E, Szocska G. 'Vacation for your teeth' - dental tourists in Hungary from the perspective of Hungarian dentists. Br Dent J 2013;215: 415- 418.

22. Osterle A, Balazs P, Delgado J. Travelling for teeth: characteristics and perspective of dental care tourism in Hungary. Br Dent J 2009;206: 4.

23. Alleman BW, Luger T, Reisinger HS, et al. Medical tourism services available to residents of the United States. J Gen Intern Med 2010;26: 492- 497.

24. Lee JY, Kearns RA, Friesen W. Seeking affective health care: Korean immigrants' use of homeland medical services. Health Place 2010;16: 108- 115.

25. Vequist D, Stackpole I. Dental tourism: an opportunity for public health. Interview by Lois K Cohen. Compendium of Continuing Education in Dentistry. Jamesburg, New Jersey 2012;33: 90, 92- 93.

26. Dahlan R, Ghazal E, dah H, et al. Impact of social support on oral health among immigrants and ethnic minorities : a systematicsalta review. PLoS One 2019;14: 1- 2 .

27. Mastaki JK. Migrant patients' satisfaction with health care services: A comprehensive review. Ital J Public Health 2010;7: 333- 343

28. Ní Ríordáin R, McCreary C. Dental patients' use of the Internet. Br Dent J 2009;207: 583- 586.

29. Mun WK, Musa G. Medical tourism in Asia: Thailand, Singapore, Malaysia, and India. Med Tour Ethics Regul Mark Heal Mobil 2012;7: 167- 186.

30. Bahadori M, Raadabadi M, Ravangard R, et al. Factors affecting dental service quality. Int J Heal Care Qual Assur 2015;28: 678- 689.

31. Tashkandi FS, Hejazi LO, Lingawi HS. 'Patients' satisfaction with dental care services provided by educational dental hospital. Int J Health Sci Res. 2017;7: 135.

32. Thuy- Pham NH, Le-Nguyen D, Nguyen K. A Value perspective of service interaction quality: the case of immigrants returning to native countries as medical tourist. Int J Quality Innov 2019;5: 1- 15.

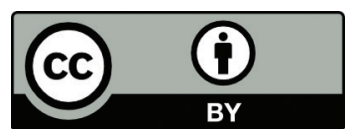

This work is licensed under a Creative Commons Attribution 